\title{
Changes in Normal Glycosylation Mechanisms in Autoimmune Rheumatic Disease
}

John S. Axford, Nazira Sumar, Azita Alavi, David A. Isenberg, Adam Young, Katherine B. Bodman, and Ivan M. Roitt

Department of Rheumatology Research/Immunology, University College and Middlesex School of Medicine,

London WIP 9PG, United Kingdom

\begin{abstract}
To investigate potential mechanisms controlling protein glycosylation we have studied the interrelationship between lymphocytic galactosyltransferase (GTase) activity and serum agalactosylated immunoglobulin $G$ levels $(G(0))$ in healthy individuals and patients with rheumatoid arthritis and non-autoimmune arthritis. In RA there was reduced GTase activity and increased $G(0)$. A positive linear correlation between $B$ and $T$ cell GTase was found in all individuals. The relationship between $G T a s e$ and $G(0)$ was found to be positive and linear in the control population and negative and linear in the RA population. Sulphasalazine therapy maintained normal levels of GTase and caused a reduction in $G(0)$ in the $R A$ population. IgG anti-GTase antibodies (abs) were significantly increased in the RA population, whereas IgM anti-GTase abs were significantly decreased in both the RA and the non-autoimmune arthritis groups. These data describe a defect in RA lymphocytic GTase, with associated abnormal $G(0)$ changes, which is corrected by sulphasalazine. A possible regulatory mechanism controlling galactosylation in normal cells is suggested, in which there is parallel control of B and T cell GTase. IgM anti-GTase abs may be integrated into this normal regulatory process. This is disrupted in RA, where the positive feedback between GTase and G(0) is lost and there is an associated increase in IgG anti-GTase abs, which may result from isotype switching as IgM anti-GTase abs are reduced. We suggest that these mechanisms are of relevance to the pathogenesis of RA, and that their manipulation may form part of a novel therapeutic approach. (J. Clin. Invest. 1992. 89:1021-1031.) Key words: rheumatoid arthritis - salicylazosulphapyridine • agalactosylated immunoglobulin • galactosyltransferase • antigalactosyltransferase
\end{abstract}

\section{Introduction}

Glycoproteins are ubiquitous in nature (1) and come in a variety of shapes and forms (2). The majority of molecules involved in the immune system are glycosylated, for example, the HLA class II molecules and the T cell receptor $(3,4)$, and tend to exhibit normal variation in the extent of glycosylation (5). Glycosylation changes can have profound effects on glycoprotein function (6), and the relevance of IgG glycosylation

Address correspondence to Dr. J. S. Axford, Academic Rheumatology Unit, Division of Immunology, St. George's Hospital Medical School, Cranmer Terrace, London SW17 ORE, United Kingdom.

Received for publication 18 January 1991 and in revised form 8 July 1991.

J. Clin. Invest.

(c) The American Society for Clinical Investigation, Inc.

0021-9738/92/03/1021/11 $\$ 2.00$

Volume 89, March 1992, 1021-1031 changes to the pathogenesis of RA has been the subject of much speculation (7).

The glycoprotein UDP $\beta, 1-4$ galactosyltransferase (GTase) ${ }^{1}$ is an intracellular membrane-bound enzyme that can be localized to the Golgi apparatus (8), but may also be found on the cell surface (9) and in a soluble form in milk, amniotic fluid, cerebrospinal fluid, saliva, urine, and serum (10).

The molecular role of GTase is to catalyze the transfer of galactose from UDP-galactose to an $\mathrm{N}$-acetylglucosamine acceptor during oligosaccharide elongation, for example, in IgG and IgA glycosylation (11). The gene encoding human GTase is thought to be located on chromosome 9 (12), and it may specify more than one mRNA transcript (13).

GTase seems to play a multifunctional role in normal cell physiology and has been associated with sperm-egg binding (14), cell-cell recognition (15), embryonic maturation (16), and cell development (17). GTase activity has been shown to be reduced in B lymphocytes of patients with rheumatoid arthritis (18), but this does not appear to be due to gross structural changes in either the GTase activator gene (19), the GTase gene itself, or to the presence of a soluble intracellular inhibitor (20).

Immunoglobulin $\mathrm{G}$ is a glycoprotein carrying $\mathrm{N}$-linked oligosaccharides (21) (Fig. 1) which, in the human, are predominantly located at asparagine 297 in the $\mathrm{C} \gamma 2$ domain of the $\mathrm{Fc}$ region. There is a parabolic relationship between the extent of galactosylation of the biantennary oligosaccharides and age (22), with a high percentage of agalactosylated $\operatorname{IgG}(\operatorname{IgG~G}(0)$ ) being present at birth and in old age. Oligosaccharide side chains may play an important role in the integrity of IgG as their absence alters not only the conformation of the molecule (23), but also its functional properties. For example, binding to monocyte and macrophage $F c$ receptors $(24,25)$, complement component $\mathrm{Clq}$ (26), and ability to induce cellular cytotoxicity (24), all rely on a normal degree of glycosylation. Immune complexes containing aglycosylated immunoglobulin fail to be eliminated rapidly from circulation (25), and feedback immunosuppression is lost (27).

Abnormalities of IgG glycosylation are recognized in individuals with rheumatoid arthritis (21), where a shift in the population of IgG glycoforms towards those with a higher content of $\mathrm{G}(0)$-oligosaccharides is observed in both serum and synovial fluid, when compared to age-matched controls. In some of these individuals $G(0)$ levels correlate with clinical score and disease activity (28). After extensive investigation of other disorders (29), reduced IgG-Fc galactosylation has been shown to be limited mainly to patients with juvenile chronic arthritis, tuberculosis, Crohn's disease, systemic lupus erythematosus

1. Abbreviations used in this paper: ESR, erythrocyte sedimentation rate; GTase, galactosyltransferase; G(0), agalactosylated IgG; NSAID, nonsteroidal antiinflammatory drug; PBS-T, PBS, $0.05 \%$ Tween; SASP, sulphasalazine. 


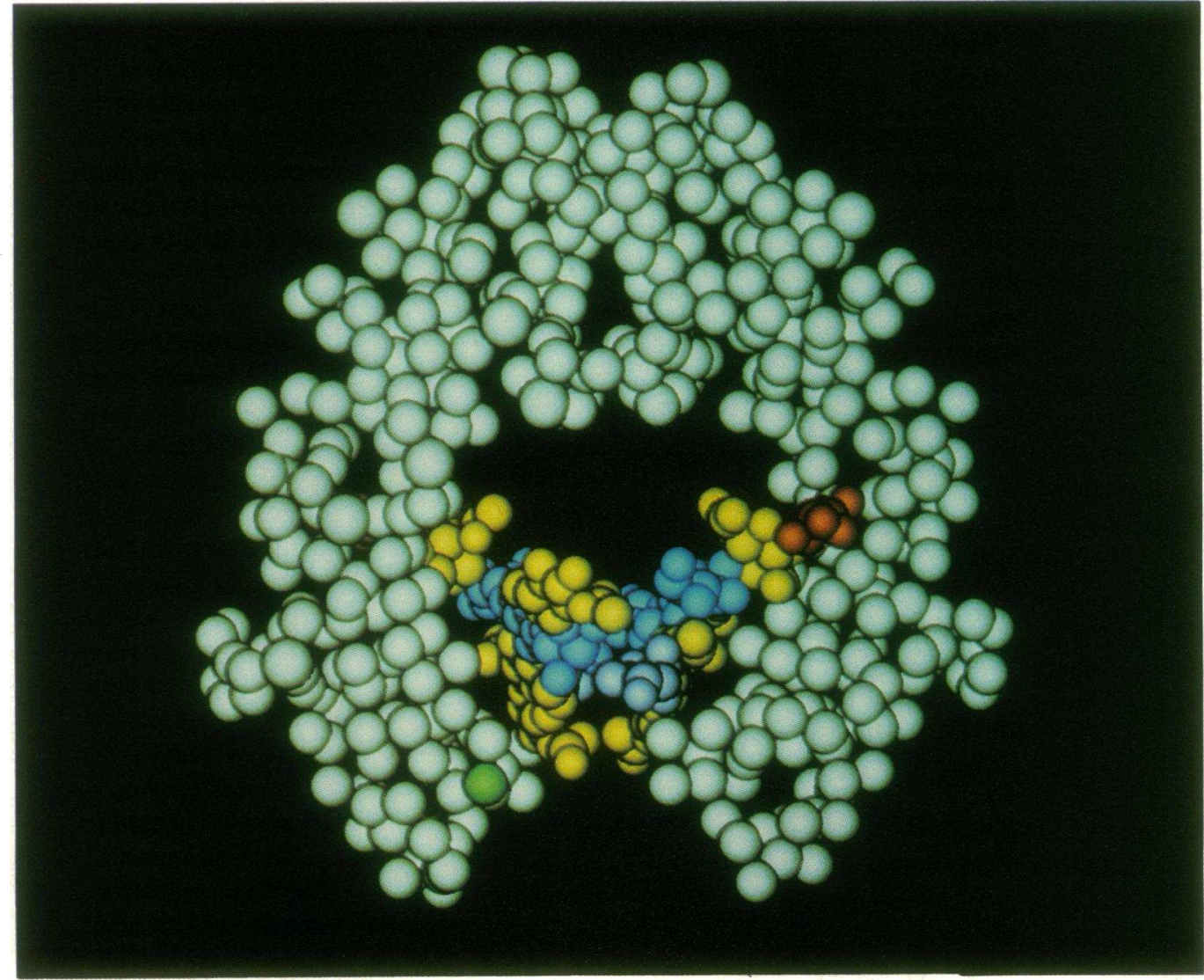

Figure 1. The Fc portion of immunoglobulin G. A computer generated model demonstrating the three-dimensional configuration of the amino acid backbone (light spheres) and the opposing biantennary oligosaccharide structures. The blue spheres represent mannose, the yellow spheres $N$-acetylglucosamine, the red spheres galactose, the gray/blue spheres fucose, and the green sphere proline 238 . The terminal galactose is absent from one of the arms of the left hand oligosaccharide moiety exposing amino acid residues that become potentially available for immune interaction. with Sjögren's syndrome, erythema nodosum leprosum (30), and Lyme disease-associated arthritis (31).

We now present data to show the interrelationship between lymphocytic GTase and serum $\mathrm{IgG} \mathrm{G(0)}$ in normal and disease conditions, the effects of drug therapy on these parameters, and the association of isotype-specific serum antigalactosyltransferase antibodies, by investigating populations of healthy individuals, patients with non-autoimmune arthritis, and those with rheumatoid arthritis.

\section{Methods}

\section{Patients and healthy individuals}

\section{THE CONTROL POPULATION}

Peripheral blood lymphocyte investigations. The control population consisted of 14 patients attending the Bloomsbury Rheumatology Unit and 18 healthy individuals. None of them had an autoimmune rheumatic disease (32). Their mean age was $54.5 \mathrm{yr}$ (range 32-78 yr) and there were 22 females. 11 members of the patient population were receiving treatment for osteoarthritis, and one individual was taking a nonsteroidal antiinflammatory drug (NSAID). The remaining three patients had ankylosing spondylitis, and two were taking NSAIDs. The healthy individuals had no complaints of arthritis and were taking no drugs.

Tonsil lymphocyte investigations. Lymphocytes were taken from tonsil tissue from nine individuals (mean age $11 \mathrm{yr}$, range 3-26 yr) who had undergone routine tonsillectomy for benign tonsillar hypertrophy.
Serum antigalactosyltransferase investigations. The healthy control population consisted of 21 individuals, which included those whose peripheral blood lymphocytes were investigated. Their mean age was $52.2 \mathrm{yr}$ (range 28-77 yr) and there were 19 females. The healthy individuals had no complaints of arthritis and were taking no drugs.

The disease control population consisted of eight individuals with ankylosing spondylitis (non-autoimmune arthritis group), as defined by the presence of arthritis, raised erythrocyte sedimentation rate, absence of autoantibodies, and characteristic axial radiographic changes. Their mean age was $55.1 \mathrm{yr}$ (range 42-69 yr), they were all male, and five were taking nonsteroidal anti-inflammatory drugs, two together with sulphasalazine (SASP)

\section{The rheumatoid arthritis patient population}

\section{PERIPHERAL BLOOD LYMPHOCYTE INVESTIGATIONS}

Population description. 32 patients (27 females), satisfying the revised American Rheumatism Association criteria for the diagnosis of rheumatoid arthritis (33), were selected at random from those attending the Bloomsbury Rheumatology Unit. Their mean age was 59.9 yr (range 28-88 yr) and they were age matched with the controls to within $10 \mathrm{yr}$.

Patient treatment. Patients were divided into three groups, according to treatment. Group $1(n=9)$ : who were taking either no medication $(n=5)$ or a NSAID $(n=4)$ only. Group $2(n=11)$ : who were taking SASP either alone $(n=3)$, in combination with a NSAID ( $n$ $=5$ ), or another drug ( $n=3$, two on prednisolone, one on azathioprine). Group $3(n=12)$ : who were taking second/third line drugs, other than SASP $(n=7)$, together with a NSAID $(n=5)$. Of these patients, five were taking D-penicillamine, four azathioprine, two prednisolone, and one sodium aurothiomalate, in conventional doses. All 
patients had been established on treatment for a minimum of two months.

Disease activity. Disease activity was determined (34), and graded one to three corresponding to "inactive/mild," "moderate," and "severe" activity.

Disease activity was not equally represented in the three treatment groups, and there were proportionately more individuals with inactive/ mild and moderate disease activity in drug groups 1 and $3(67 \%$ and $83 \%$, respectively) and with moderate and severe disease activity in drug group 2 (91\%).

SERUM ANTIGALACTOSYLTRANSFERASE INVESTIGATIONS 25 patients from the peripheral blood lymphocyte investigation group were studied. Their mean age was $61.1 \mathrm{yr}$ (range 34-87 yr), and there were 20 females. They were receiving the following treatment: no drugs $(n=5)$; NSAID alone $(n=1)$; SASP alone $(n=3)$; SASP and NSAID $(n$ $=1)$; SASP and second/third line drugs $(n=4$ : azathioprine 1, prednisolone 2, sodium aurothiomalate 1); second/third line drugs, other than SASP, alone, $(n=9$ : D-penicillamine 4, sodium aurothiomalate 2 , azathioprine 2, prednisolone 1); second/third line drugs and $\operatorname{NSAID~(n}$ = 2: D-penicillamine and chloroquine phosphate).

\section{CONSECUTIVE INVESTIGATIONS OF RA PATIENTS}

Galactosyltransferase activity analysis. Consecutive investigations were carried out on 13 patients from the RA group, described above. Seven of these patients were treated with SASP and two were also taking D-penicillamine and sodium aurothiomalate respectively. These patients were investigated on an average of 3.4 occasions (range 2-5) and followed up for an average of $8.3 \mathrm{mo}$ (range 1-12 mo). Over this period, 15 (42\%) samples were taken from patients with inactive/mild disease activity, $18(50 \%)$ from patients with moderate disease activity, and $3(8 \%)$ when there was severe disease activity. Of the remaining six patients, two were taking prednisolone and four were taking D-penicillamine, cyclophosphamide, azathioprine, and chloroquine ("other drug group"). These patients were investigated on an average of 3.2 occasions (range 2-4) and followed up for an average of $6.7 \mathrm{mo}$ (range 1-13 mo). Over this period $14(74 \%)$ samples were taken from patients with inactive/mild disease activity, $2(10 \%)$ from patients with moderate disease activity, and $3(16 \%)$ when there was severe disease activity.

Serum $\operatorname{IgG} G(0)$ analysis. Consecutive investigations were carried out on a second group of 12 patients with RA ( 6 female, mean age 50 yr, range 23-69), before they received medication $(n=12)$ and after they were established on SASP treatment, at a conventional dose ( $n$ $=8$ ). A mean period of $10 \mathrm{mo}$ (range 1-32) separated the investigations while no treatment was being given and a mean period of 20 mo (range 13-34) separated the investigations conducted just before the start of SASP and that carried out once the patients were established on SASP.

\section{Experimental procedures}

Isolation of $B$ and $T$ cell-enriched populations from human peripheral blood. Isolation of enriched populations of $\mathrm{B}$ and $\mathrm{T}$ lymphocytes has previously been described (18). Briefly, peripheral blood was obtained by venesection and depleted of monocytes by incubation with carbonyl iron, followed by separation with a magnet. Peripheral blood lymphocytes were then separated by means of Ficoll-Hypaque (35). Cell purity was assessed by May-Grunwald-Giemsa staining, the lymphocytes accounting for at least $95 \%$ of the total population. The $B$ and $T$ cells were further separated by rosetting with neuraminidase-treated sheep red blood cells. Assessment of cell purity by rerosetting showed at least $95 \%$ rosettes in the $\mathrm{T}$ cell population and no more than $10 \%$ rosettes in the B cell population.

The lymphocytes were suspended in $100 \mathrm{mmol} / \mathrm{liter}$ Tris- $\mathrm{HCl}$ buffer (pH 6.8) containing $0.1 \%$ Triton X-100 (Sigma Chemical Co., St. Louis, MO) and 0.1\% 2-mercaptoethanol (BDH Chemicals Ltd., Dagenham, Essex, UK), frozen and thawed twice, and homogenized in a glass homogenizer. The homogenate was centrifuged at $10,000 \mathrm{rpm}$ for $10 \mathrm{~min}$, and the supernatant assayed for enzyme activity.
Isolation of a B cell enriched-population from human tonsils. GTase was obtained for assay in an identical way to that for mixed peripheral lymphocytes. FACS ${ }^{\circledast}$ analysis verified that the tonsillar lymphocytes obtained were composed of $>65 \%$ B cells (data not shown).

Determination of lymphocytic galactosyltransferase activity. The standard incubation medium for the assay contained: $0.5 \mathrm{mmol} / \mathrm{liter}$ ATP (Sigma), $20 \mathrm{mmol} /$ liter manganous chloride (BDH), $0.1 \mathrm{mmol} /$ liter UDP-galactose (Sigma), $1 \mu \mathrm{Ci}$ UDP- $\left[{ }^{3} \mathrm{H}\right]$ galactose (Amersham International, Amersham, Bucks., UK), $1 \mathrm{mg}$ ovalbumin (Sigma) in $100 \mathrm{mmol} /$ liter Tris- $\mathrm{HCl}$ buffer ( $\mathrm{pH} \mathrm{6.8)}$, to a total volume of $100 \mu$, after addition of $20 \mu$ enzyme extract. The mixture was incubated, in duplicate, for $2 \mathrm{~h}$ in a shaking water bath at $37^{\circ} \mathrm{C}$. The reaction was stopped by the addition of $2 \mathrm{ml} 1 \%$ phosphotungstic acid in $0.5 \mathrm{mmol} /$ liter hydrochloric acid. The precipitate was filtered onto glass microfiber filters (GF/A; Whatman Inc., Clifton, NJ) washed, dried, and counted. Protein concentration was estimated (Bio-Rad Laboratories, Richmond, CA) and the enzyme activity expressed as $\mathrm{cpm} / \mathrm{mg}$ protein $\cdot 10^{5}$. In those patients investigated on more than one occasion, the individual patient activities were averaged and their means determined for comparison of the two treatment groups. The coefficient of variability of the assay was $4.4 \%$. Results for each group studied are presented as mean $\pm \mathrm{SEM}$. The catalytic reaction was characterized by performing dilution experiments with the enzyme extract and inhibiting the reaction by omitting manganous chloride or by the addition of uridine diphosphate (100 mmol/liter) (data not shown).

Measurement of immunoglobulin $G$ galactosylation. A novel lectinbinding method (36) was employed to determine the $G(0)$ value in the patients studied. Essentially, this involved dot blotting IgG samples onto nitrocellulose and boiling to expose the carbohydrate moieties. The blots were then treated with biotinylated Bandeiraea simplicifolia lectin and Ricinus communis agglutinin, which bind to $N$-acetylglucosamine and galactose, respectively (Fig. 2). Binding was detected using streptavidin-horseradish peroxidase conjugate and developing with chloronaphthol. Optical density ratios were determined with a video densitometer (Bio-Rad) and the $G(0)$ content determined by comparison with a standard curve constructed with IgG of known $G(0)$ values, determined by sequence analysis (21). $G(0)$ values are expressed both as the proportion (\%) of total serum IgG molecules lacking galactose and as the number of standard deviations from the mean of a normal population of comparable age (36). Results are given as mean \pm SEM.

Measurement of serum antigalactosyltransferase antibodies. A direct binding ELISA technique was used. Immuno plates (Nunc, Roskilde, Denmark) were coated with bovine GTase (Sigma) at $1 \mu \mathrm{g} / \mathrm{ml}$ in borate buffer. The plates were washed $3 \times$ with PBS, $0.05 \%$ Tween (PBS-T), and blocked with PBS, 3\% BSA for $2 \mathrm{~h}$ at room temperature.

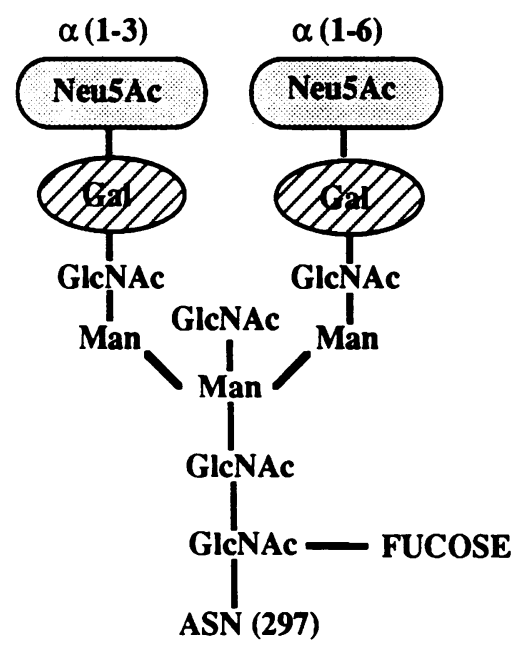

Figure 2. The biantennary complex oligosaccharide structure found at the Fc region of human serum IgG. There is a common pentasaccharide core containing two $\alpha$-mannosyl residues attached to a $\beta$ mannosyl-di- $N$-acetylchitobiose unit. Terminal sialic acid (Neu5Ac) is usually found in the Fab region of IgG, whereas terminal galactose $(\mathrm{Gal})$ and $N$-acetylglucosamine (GlcNAc) are more common in the Fc re-

gion. Fucose and the GlcNAc bisect are relatively uncommon in the Fc sugars. $G(0)$ refers to oligosaccharides completely lacking galactose. 
The serum samples, diluted in PBS-T, $1 \%$ BSA, 3\% goat serum at $1 / 400$, were added in duplicate and incubated for $2 \mathrm{~h}$ at room temperature. The plates were washed $3 \times$ with PBS-T, followed by the addition of goat anti-human IgG/M alkaline phosphatase conjugate at $1 / 1,000$, incubated overnight at $4^{\circ} \mathrm{C}$, washed $3 \times$ with PBS-T, and developed using phosphatase substrate tablets (104; Sigma). The OD was read at $410 \mathrm{~nm}$, corrected for background nonspecific binding, and the results expressed as OD ratio of a positive sample.

Statistics. Statistics used in analyzing the data are the Student's $t$ test, simple and polynomial regression analysis, and standard error of the mean, and were calculated using Statworks version 1.2 (Cricket Software Inc., Philadelphia, PA). The standard normal deviant test was used to compare regression analyses.

\section{Results}

\section{Glycosylation differences within the control population}

Lymphocytic GTase activity. No difference in GTase activity was observed within the control population (Table I), when divided by sex or the presence or absence of non-autoimmune arthritis. Regression analysis of the total data (Fig. 3) revealed a fairly strong positive linear relationship between $B$ and $T$ cell GTase activities. Regression analysis of the relationship between GTase activity and age in the total control population revealed no association. No difference in GTase activity was observed between tonsil lymphocytic GTase activity (mean \pm SEM: $31 \pm 6 \mathrm{cpm} / \mathrm{mg}$ protein $\cdot 10^{5}$ ) and the peripheral B cell GTase activity of the total control population $(35 \pm 4$ $\mathrm{cpm} / \mathrm{mg}$ protein $\cdot 10^{5}$ ).

Immunoglobulin $G$ galactosylation. The mean serum $\mathrm{G}(0)$ $( \pm \mathrm{SEM})$ of the total control population was $31.3 \pm 1.5 \%$; $0.36 \pm 0.2 \mathrm{SD}$ above the age-related population mean previously established. There was no difference in serum $G(0)$ values between the normal and the non-autoimmune arthritis control individuals (normal: $G(0) 31.5 \pm 2.3 \% ; 0.46 \pm 0.3 \mathrm{SD}$ above the age-related population mean. Non-autoimmune arthritis: $G(0)$ $31.1 \pm 2.0 \% ; 0.24 \pm 0.3 \mathrm{SD}$ above the age-related population mean). Regression analysis (Fig. 4) revealed weak linear positive relationships between $\mathrm{B} / \mathrm{T}$ cell $\mathrm{GTase}$ and $\mathrm{G}(0)(r=0.263$ and 0.211 for B and T cell GTase, respectively; $P<0.05$ ).

\section{Glycosylation differences within the $R A$ population}

OVERALL LYMPHOCYTIC GTase ACTIVITY

$B$ and $T$ cell populations. Both B and T cell GTase activities (Table II, Figs. 5 and 6 ) were significantly reduced by $40 \%$ ( $P$ $<0.01)$ and $29 \%(P<0.05)$, respectively, when patients were compared to the age-matched control population. There was no difference in GTase activity when the female $(n=27)$ and the male $(n=5)$ patients were compared: female, $22 \pm 4$ and $24 \pm 4 \mathrm{cpm} / \mathrm{mg}$ protein $\cdot 10^{5} ;$ male, $19 \pm 7$ and $9 \pm 4 \mathrm{cpm} / \mathrm{mg}$ protein $\cdot 10^{5}$ for $B$ and $T$ cells, respectively.

Regression analysis (Fig. 3) revealed a strong positive linear relationship between the total B and T cell GTase activities.

THE RELATIONSHIP OF LYMPHOCYTIC GTaSe ACTIVITY WITH DRUG THERAPY AND DISEASE ACTIVITY

The $B$ cell population. In drug groups 1 and 3 (Fig. 5), GTase activity was significantly reduced by $60 \%(P<0.02)$ and $40 \%$ $(P<0.05)$, respectively, when compared to the total control population. In contrast, there was no difference when the GTase activity of drug group 2 taking sulphasalazine was compared to the total control population. Furthermore, GTase ac- tivities in drug groups 1 and 3 individuals were significantly less than those in drug group $2(n=8)$ who were taking SASP, in the absence of second/third line drugs, $(35 \pm 9 \mathrm{cpm} / \mathrm{mg}$ protein $\cdot 10^{5}, P<0.05$ ).

B cell GTase activity did not vary significantly with disease activity (inactive/mild $[n=9], 14 \pm 3 \mathrm{cpm} / \mathrm{mg}$ protein $\cdot 10^{5}$; moderate $[n=8], 25 \pm 7 \mathrm{cpm} / \mathrm{mg}$ protein $\cdot 10^{5} ;$ severe $[n=15]$, $24 \pm 6 \mathrm{cpm} / \mathrm{mg}$ protein $\cdot 10^{5}$ ). Also, there was no correlation between B cell GTase activity and erythrocyte sedimentation rate (ESR).

The T cell population. In drug groups 1 and 3 (Fig. 6) GTase activity was significantly reduced $(P<0.05)$ by $42 \%$ and $32 \%$, respectively, when compared to the total control population. As was the case with B cells, there was no significant difference when GTase activity of drug group 2 was compared to the total control population, and again a significant reduction in GTase activities was observed in patients in drug groups 1 and 3 when compared to those in drug group $2(n=8)$ who were taking SASP, in the absence of second/third line drugs, $(35 \pm 12 \mathrm{cpm} /$ mg protein $\left.\cdot 10^{5}, P<0.05\right)$. T cell GTase activity did not vary significantly with disease activity. (Inactive/mild [ $n=9$ ], $18 \pm 4$ $\mathrm{cpm} / \mathrm{mg}$ protein $\cdot 10^{5}$; moderate $(n=8), 22 \pm 5 \mathrm{cpm} / \mathrm{mg}$ protein $\cdot 10^{5}$; severe $(n=15), 27 \pm 10 \mathrm{cpm} / \mathrm{mg}$ protein $\left.\cdot 10^{5}\right)$; and, similarly, there was no correlation between $T$ cell GTase activity and ESR.

Regression analysis revealed a strong positive linear relationship between B and T cell GTase activity in both drug group 1 and 2 patients $(r=0.824$ and 0.772 for groups 1 and 2 , respectively, $P<0.01$ ), but a similar relationship was not found with drug group 3 patients $(r=0.240)$.

\section{IMMUNOGLOBULIN G GALACTOSYLATION}

In accordance with previous studies $(21,36)$, the $G(0)$ values of the RA population $(38.1 \pm 1.9 \% ; 1.1 \pm 0.2 \mathrm{SD}$ above the age-related population mean) were significantly greater than those of the corresponding age-matched control population $(P<0.01)$. There was no significant difference between $G(0)$ values analyzed according to sex, drug group, and disease activity, and there was no correlation between $G(0)$ and age in this population. Regression analysis (Fig. 7) revealed a negative linear relationship between $\mathrm{G}(0)$ and B cell GTase, but not $T$ cell GTase activity $(r=-0.16, P=0.1)$. Comparison of regression values for $G T$ ase and $G(0)$ between the control and RA populations revealed a significant difference for both $B$ cells $(P<0.01)$ and T cells $(P<0.05)$.

Table I. Lymphocytic Galactosyltransferase Activity of the Control Population, Analyzed According to Sex and the Presence or Absence of Non-autoimmune Arthritis

\begin{tabular}{|c|c|c|c|}
\hline \multirow{2}{*}{$\begin{array}{c}\text { Control } \\
\text { population }\end{array}$} & \multirow[b]{2}{*}{ Number } & \multicolumn{2}{|c|}{ Mean enzyme activity \pm SEM } \\
\hline & & B Cell & T Cell \\
\hline & & \multicolumn{2}{|c|}{$\mathrm{cpm} / \mathrm{mg}$ protein $\cdot 10^{\mathrm{s}}$} \\
\hline All & 32 & $35 \pm 4$ & $31 \pm 4$ \\
\hline Male & 10 & $38 \pm 8$ & $33 \pm 7$ \\
\hline Female & 22 & $32 \pm 5$ & $30 \pm 4$ \\
\hline No arthritis & 18 & $36 \pm 6$ & $31 \pm 5$ \\
\hline Arthritis & 14 & $31 \pm 7$ & $30 \pm 6$ \\
\hline
\end{tabular}



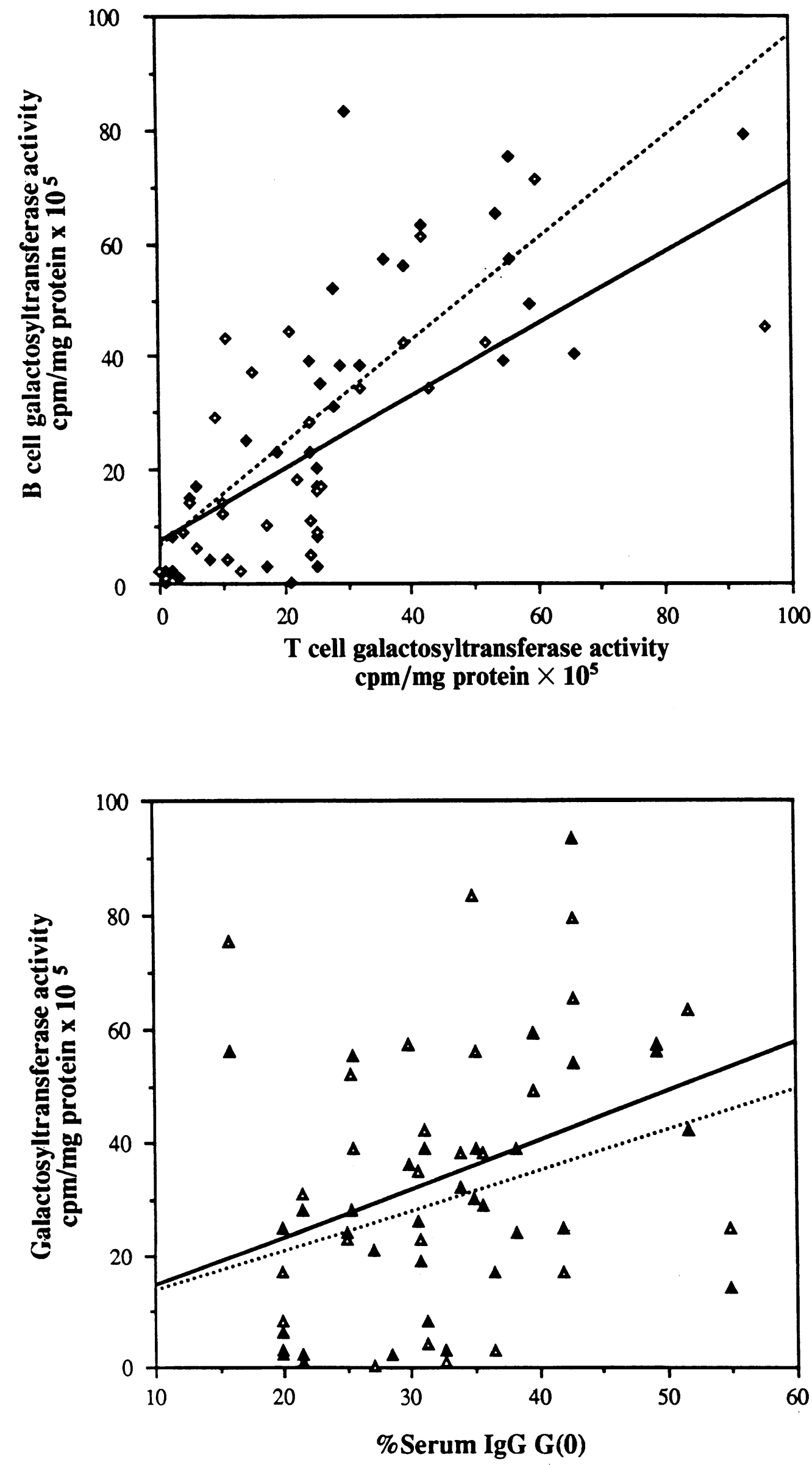

Figure 3. Regression analysis of control (closed diamonds and broken line, $r=0.770, P$ $<0.001$ ) and RA (open diamonds and unbroken line, $r$ $=0.691, P<0.001)$ paired $\mathrm{B}$ and $\mathrm{T}$ lymphocytic galactosyltransferase activities.
Figure 4. Regression analysis of paired B (open triangles and unbroken line) and $\mathrm{T}$ (closed triangles and dotted line) lymphocytic galactosyltransferase activities and serum agalacto-immunoglobulin $\mathbf{G}$ (percent serum IgG $G(0))$ in the control population $(r=0.263$ and 0.211 for B and T cells, respectively, $P<0.05$ ). 
Table II. B and T Lymphocytic Galactosyltransferase Activity of the Rheumatoid Arthritis Population

\begin{tabular}{|c|c|c|c|}
\hline \multirow[b]{2}{*}{ Population } & \multirow[b]{2}{*}{ Number } & \multicolumn{2}{|c|}{ Mean enzyme activity \pm SEM } \\
\hline & & B cell & $T$ cell \\
\hline & & \multicolumn{2}{|c|}{$\mathrm{cpm} / \mathrm{mg}$ protein $\cdot 10^{5}$} \\
\hline Control & 32 & $35 \pm 4$ & $31 \pm 4$ \\
\hline RA & 32 & $21 \pm 3^{*}$ & $22 \pm 4^{\ddagger}$ \\
\hline
\end{tabular}

${ }^{*} P<0.01 ;{ }^{\ddagger} P<0.05$

SERUM ANTIGALACTOSYLTRANSFERASE INVESTIGATIONS In the RA patients (Fig. 8), IgG anti-GTase antibodies were significantly increased when compared to the healthy control population: RA, $0.274 \pm 0.043$; healthy, $0.149 \pm 0.014, P$ $=0.006$; and $9 / 25$ patients had values greater than the healthy mean control value plus 2 SD. No increase in IgG anti-GTase antibodies was found in the non-autoimmune arthritis group $(0.125 \pm 0.018)$ when compared to the healthy control population, but there was a significant increase $(P=0.03)$ in IgG anti-GTase antibodies in the RA population when compared to the non-autoimmune arthritis group.

In both the RA and the non-autoimmune arthritis groups, IgM anti-GTase antibodies were significantly decreased when compared to the healthy control population. RA, $0.524 \pm 0.032$ $(P<0.015)$; non-autoimmune arthritis, $0.301 \pm 0.033,3 / 8$ less than the healthy mean -2 SD $(P<0.001)$; healthy, $0.640 \pm 0.042$, and, furthermore, the level of IgM anti-GTase abs was significantly less in the non-autoimmune arthritis group in comparison to the RA group $(P<0.001)$.

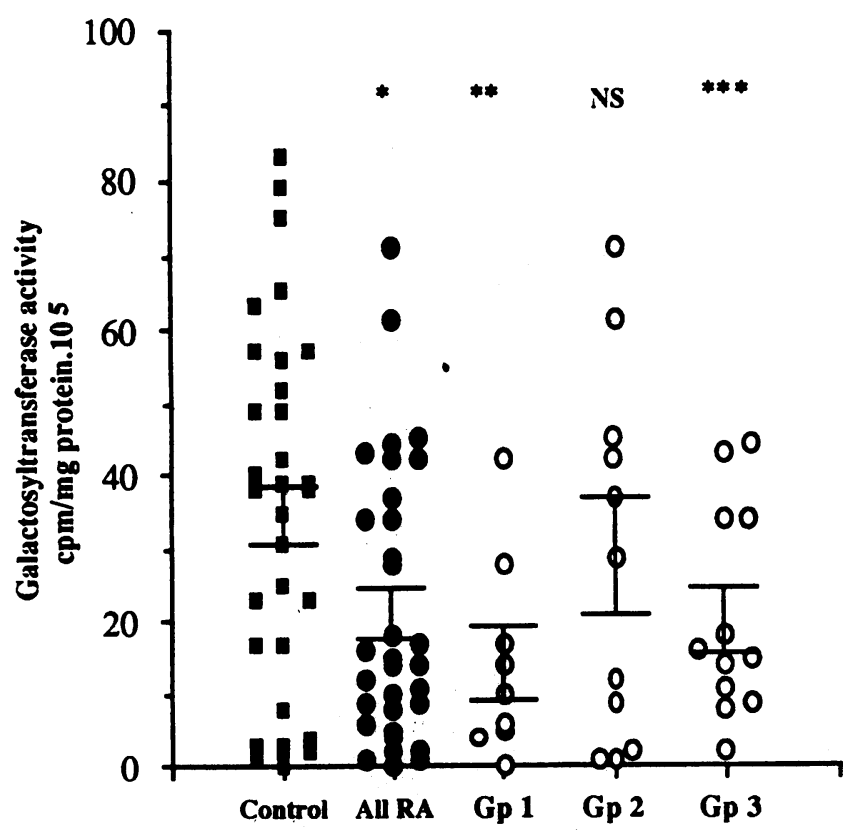

Figure 5. B lymphocytic galactosyltransferase activity (mean cpm/mg protein $\cdot 10^{5} \pm$ SEM) in the total RA population and divided according to drug therapy. Control: $35 \pm 4$. All RA: $21 \pm 3$. Gp1 (NSAID or no drugs): $14 \pm 5$. Gp2 (SASP): $28 \pm 8$. Gp.3 (other second/third line therapy): $21 \pm 4$. Bars define the mean \pm SEM. (Significance of difference from controls: ${ }^{*} P<0.01 ;{ }^{* *} P<0.02 ;{ }^{* * *} P<0.05$ ).

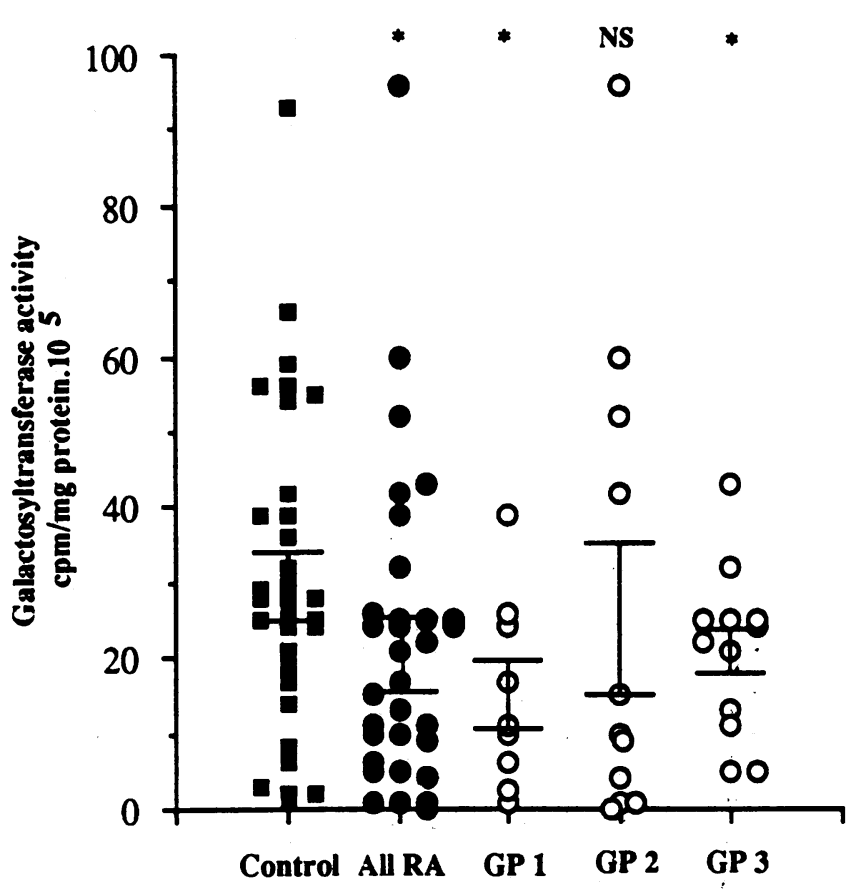

Figure 6. T lymphocytic galactosyltransferase activity (mean $\mathrm{cpm} / \mathrm{mg}$ protein $\cdot 10^{5} \pm$ SEM) in the total RA population and divided according to drug therapy. Control: $31 \pm 4$. All RA: $22 \pm 4$. Gpl (NSAID or no drugs): $18 \pm 4$. Gp2 (SASP): $26 \pm 10$. Gp.3 (other second/third line therapy): $21 \pm 3$. Bars define the mean \pm SEM. (Significance of difference from controls: ${ }^{*} P<0.05$ ).

No association was found between the presence of antiGTase antibodies and disease activity, ESR, presence/titer of IgM rheumatoid factor, and drug treatment.

CONSECUTIVE PATIENT INVESTIGATION

Galactosyltransferase activity. In the group treated with drugs other than SASP ( $n=6,19$ investigations), there was a significant decrease in the B cell GTase activity $(13 \pm 2 \mathrm{cpm} / \mathrm{mg}$ protein $\cdot 10^{5}$ ) when compared to both the total control population $(P<0.05)$ and the consecutive patient group taking SASP (Fig. $9, P<0.05)$. The T cell GTase activity $(18 \pm 4 \mathrm{cpm} / \mathrm{mg}$ protein $\cdot 10^{5}$ ) was not different from the total control population, but was significantly reduced when compared to the consecutive patient group taking SASP $(P<0.05)$.

Immunoglobulin $G$ galactosylation. In those patients (RA second group) observed on two occasions before sulphasalazine treatment was commenced, there was no significant difference between the paired serum IgG $\mathrm{G}(0)$ values $(33.8 \pm 2.5 \%$; $0.9 \pm 0.3 \mathrm{SD}$ and $28.0 \pm 2.3 \% ; 0.02 \pm 0.03 \mathrm{SD}$ above the age-related population mean). However, there was a significant difference in paired serum $\mathrm{G}(0)$ values (Fig. 10) taken before and after sulphasalazine treatment was begun $(35.4 \pm 4.0 \% ; 1.0 \pm 0.5$ SD and $23.5 \% \pm 1.6 ;-0.7 \pm 0.2$ SD from the age-related population mean, respectively, $P<0.01$ ).

\section{Discussion}

In the normal population, no difference in lymphocytic GTase activity was observed with age or sex, and $G(0)$ values fell within the previously established range $(21,36)$. The age association with IgG-galactosylation relates to agalactosylated chains only, and not those that are partially or completely galactosyl- 


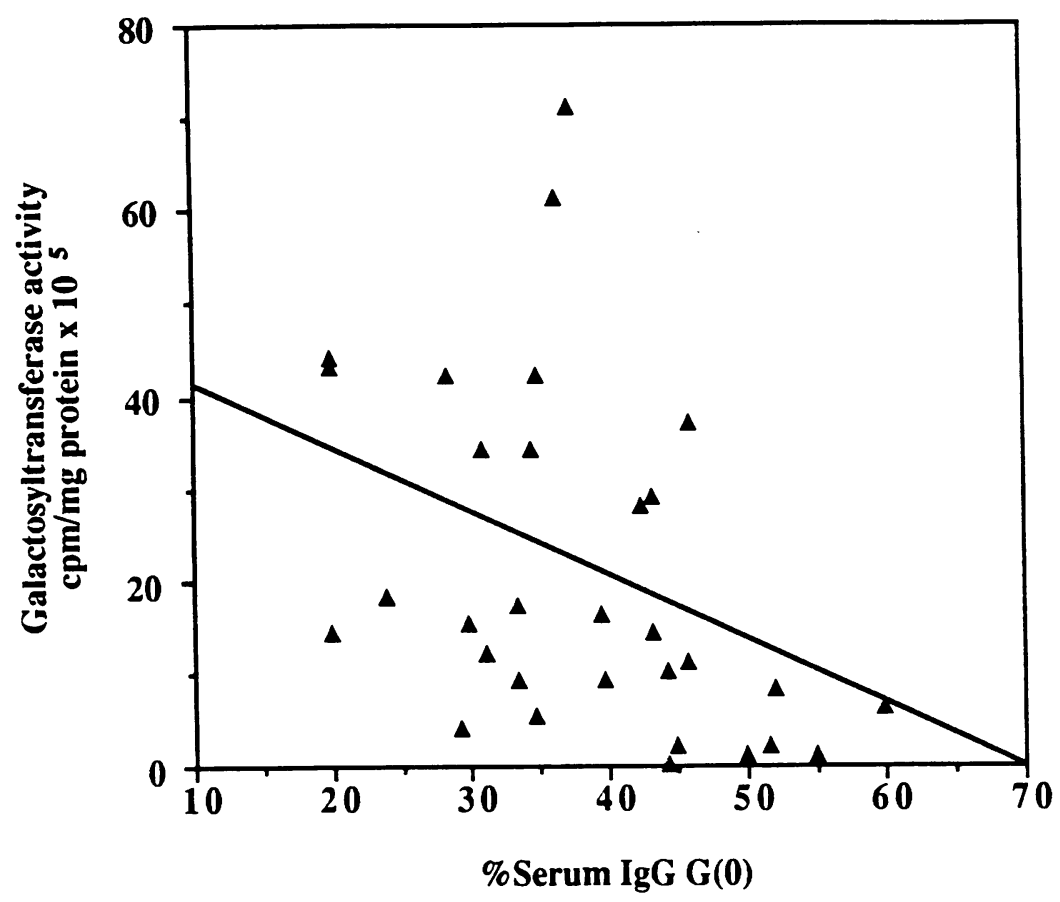

Figure 7. Regression analysis of paired B lymphocytic galactosyltransferase activity and serum agalacto-immunoglobulin $\mathrm{G}$ values (percent serum $\mathrm{IgG} \mathrm{G}(0)$ ) in the rheumatoid arthritis population $(r=-0.338, P$ $<0.004)$. There is a significant difference $(P<0.01)$ when this value is compared with the control regression value $(r=0.263)$. ated. Subtle age-related changes may therefore not relate to total GTase activity, but they could become apparent if isoenzyme activities were analyzed. GTase activity in normal peripheral and tonsil $B$ cells was found to be equivalent, and it may be assumed, therefore, that values obtained from peripheral lymphocytes are likely to be representative of the overall normal B and $T$ cell population.

Significantly, no changes were noted in $G(0)$ values and GTase activity in the presence of non-autoimmune arthritis.
This would confirm the suitability of these patients as controls and would imply that mediators of inflammation within the joint, for example, reactive oxygen species (37), have no appreciable effect on these parameters. An association between lymphocytic GTase and $\mathrm{G}(0)$ values would be expected, and a positive linear relation was apparent in the control group, which may indicate a positive feedback mechanism controlling IgG galactosylation. Changes in glycosylation pattern may be part of normal cell physiology and a controlling mechanism me-

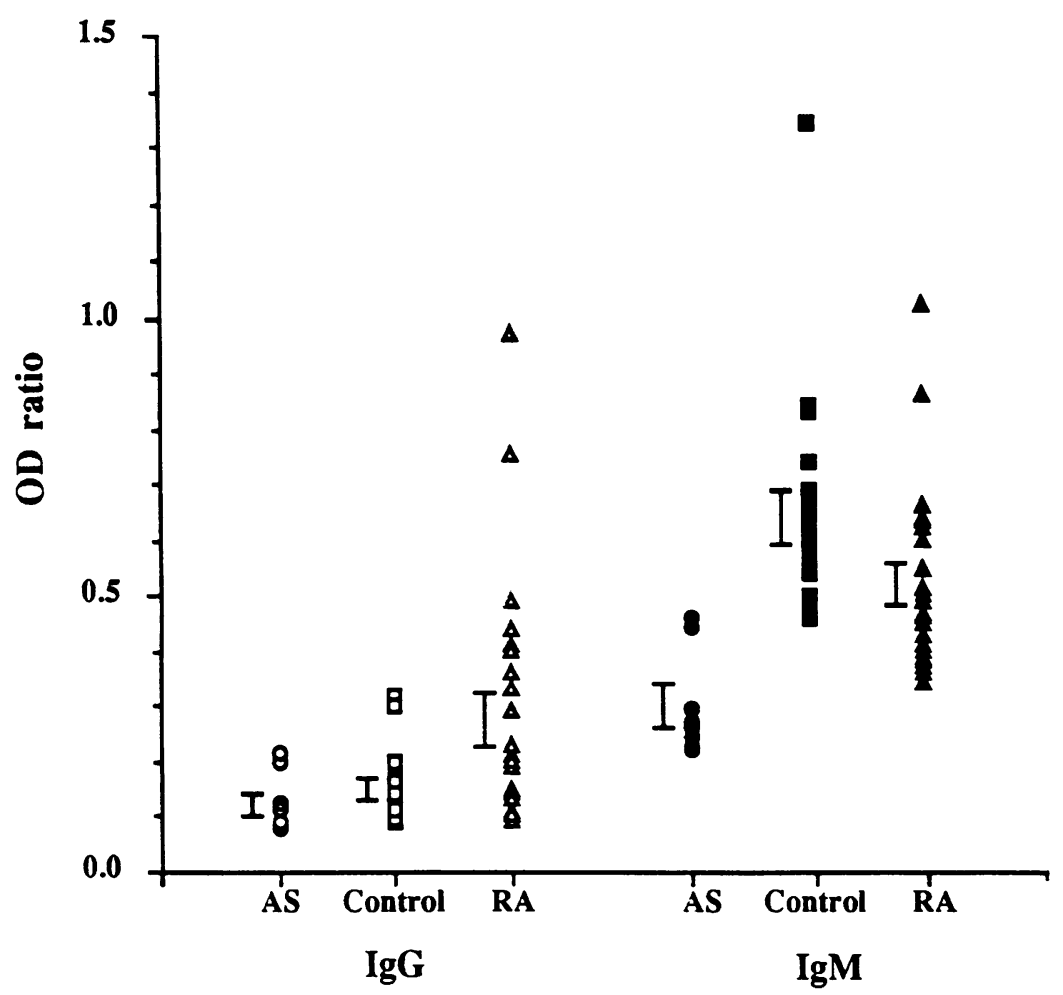

Figure 8. A comparison of serum anti-GTase antibodies ( $G$ and $M$ isotypes) showing increased levels of IgG anti-GTase abs in patients with RA when compared to the healthy control population $(84 \%, P$ $=0.006$ ) and the non-autoimmune arthritis (AS) population $(119 \%, P=0.03)$. IgM anti-GTase abs were reduced in both the RA $(18 \%, P=0.015)$ and non-autoimmune arthritis $(53 \%, P=0.0001)$ populations, when compared to the healthy control population and also when the RA and non-autoimmune arthritis populations were compared $(42 \%, P=0.001)$. 


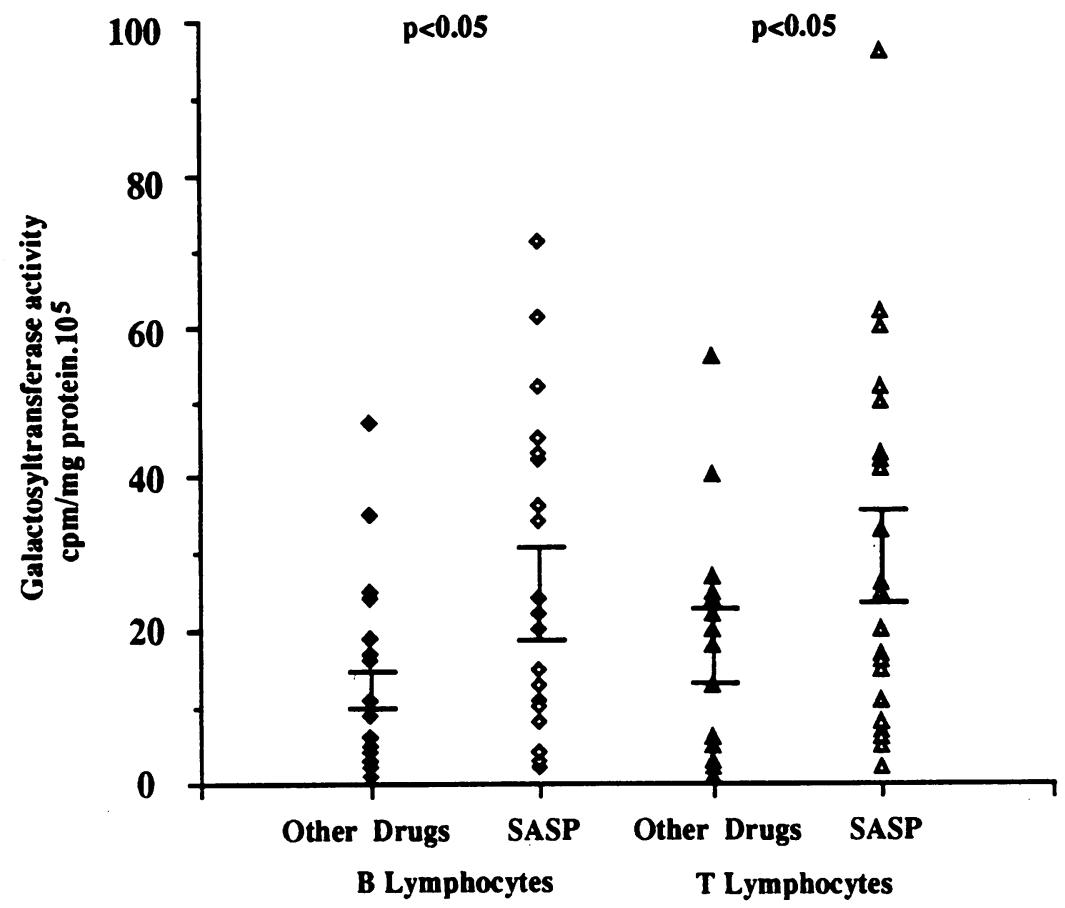

Figure 9. A comparison of lymphocytic GTase activity in RA patients $(n=13)$ taking second/third line drugs other than SASP (Other Drugs, $n=6,19$ investigations) and those taking SASP ( $n=7,24$ investigations), showing a significant reduction $(P<0.05)$ in lymphocytic GTase activity within the RA group taking other drugs. There was no difference in lymphocytic GTase activity between the SASP group and the total control population. diating these changes may operate. An association between paired B and T cell GTase activities was detected, and this may suggest parallel regulatory control.

In RA, previous data indicating a reduced B cell GTase activity (18) have been confirmed when the sample population was increased, and these findings have since been verified (38). A positive correlation between $B$ and $T$ cell GTase activity was again found, although the use of certain second and third line drugs (group 3) obscured this relationship, which may indicate that these drugs interfere with B and T cell control. G(0) and B cell GTase values were weakly associated, but in contrast to the normal population, a negative rather than a positive relationship was observed. This may indicate a breakdown in the normal regulatory mechanisms. No significant association was found between $T$ cell $G$ Tase and $G(0)$, which may also indicate an interruption in normal $\mathrm{T}$ cell GTase control.

No relationship between clinical disease activity and GTase activity or $G(0)$ values was apparent in the RA patients studied, which contrasts with previously reported $G(0)$ observations in individual patients (28). This may suggest that drug suppression of inflammation obscures ongoing disease activity. Perhaps the development of joint erosions or the presence of inflammatory mediators within the joint would be a more appropriate, although impractical, measure of disease activity in this study. However, the lack of association with clinical disease activity and correlation between GTase and $G(0)$ points to the abnormality being primarily a synthetic defect rather than being due to inflammation (37). In this respect, additional evi-

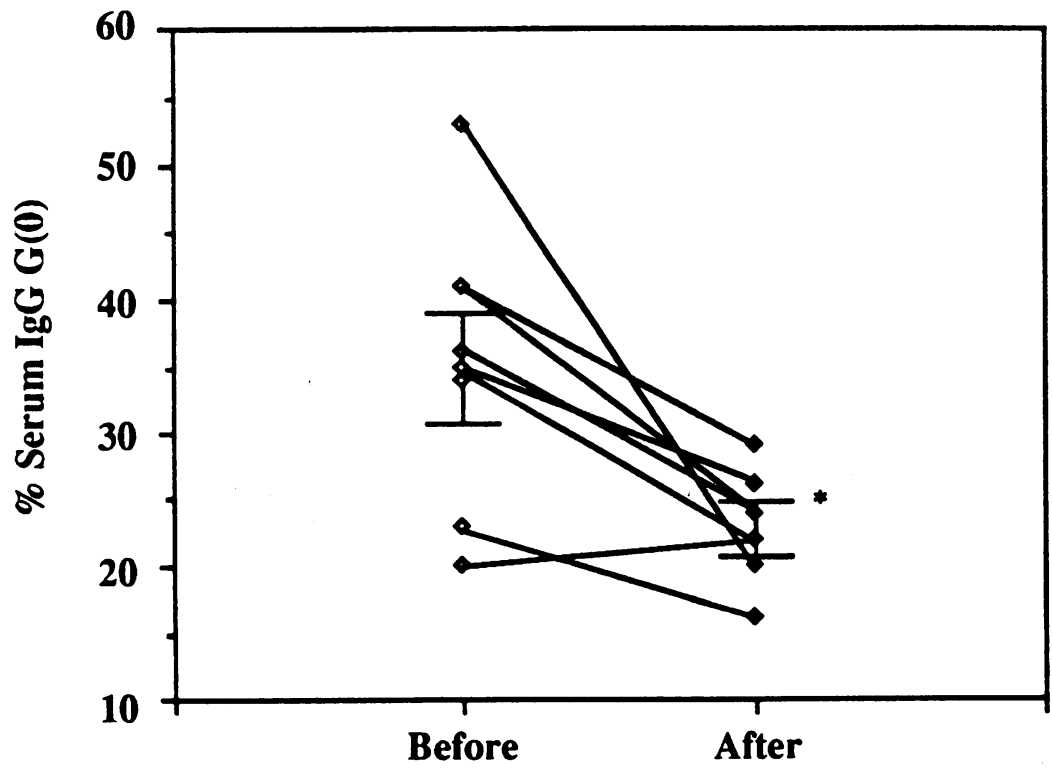

Figure 10. A comparison of the serum agalacto-immunoglobulin $\mathrm{G}$ (percent serum IgG G[0]) values for paired samples before and after SASP treatment, showing a significant decrease in mean value with treatment $(* P<0.01)$. The bars define the mean \pm SEM values. 
dence is available to add weight to the suggestion that a synthetic lymphocyte defect is the primary cause. Firstly, RA B cells synthesize agalactosylated-IgG when stimulated in vitro (39), whereas normal B cells do not. Secondly, inflammation in early Lyme disease is not associated with defective glycosylation, whereas the development of arthritis in the same patients is (31). Finally, early synovitis is only associated with increased $\mathrm{G}(0)$ in those patients that subsequently go on to develop RA (40). One must also consider that $G(0)$ changes have been observed to occur as part of normal physiological processes, which are unlikely to be due to inflammatory events. For example, $G(0)$ age changes have already been discussed (22) and, interestingly, serum IgG from pregnant women with $\mathrm{RA}$ is found to contain more galactose and sialic acid than normal IgG (41). This may suggest that clinical improvement of RA in pregnancy (42) may be associated with a temporal compensation of the undergalactosylation of IgG. The clinical score and $\mathrm{G}(0)$, however, subsequently reverse during the postpartum period (43).

A wide range of $\mathrm{GT}$ ase and $\mathrm{G}(0)$ values is observed in both the normal and RA populations, which may imply that these changes are one of a number of RA susceptibility factors; however, to date, $\mathrm{G}(0)$ associations with RA susceptibility/protective factors, for example, sex and HLA haplotype, have not been reported. In this respect, glycosylation defects may occur in other molecules of the immunoglobulin supergene family, either simultaneously or asynchronously. It may be more pertinent, therefore, to evaluate specific GTase isoenzyme changes rather than total enzyme activities, and more meaningful to examine individual patient fluctuations in glycosylation values, as these changes may be highly patient specific. Other diseases are associated with glycosylation changes and, perhaps, the mechanism of these changes may have some relevance to the pathogenesis of autoimmunity. Reduced activity of a glycosaminoglycan glycosyltransferase (44) has been reported in hereditary collagen disease and depressed levels of serum GTase are found in patients with cystic fibrosis (45). Elevation of serum GTase activity has been reported in the presence of tumor tissue (46), and serial determinations are thought to correlate with clinical status (47). Furthermore, cancer-associated isoenzyme changes have also been observed (48).

When the RA population was divided according to drug therapy, there was little difference in GTase activity between those taking no medication or NSAIDs (group 1) and those taking second or third line drugs (group 3), which were both significantly reduced in comparison to the control population. These data would indicate that drug therapy itself does not reduce GTase activity. However, no reduction was noted in B or $\mathrm{T}$ cell GTase activity in those taking SASP, when compared to the control population. Furthermore, when those taking SASP were compared to those in drug groups 1 and 3, there was a significant reduction in activity in the other drug groups when compared to the SASP group. This finding has since been observed in six other patients taking SASP (data not shown). When seven of the patients from group 2 of the RA cohort were investigated on a number of occasions once they had been established on SASP, the effect of SASP on GTase activity was maintained, in contrast to those taking other drugs. A longitudinal study of a different group of RA patients produced entirely comparable results in that a significant decrease in $G(0)$ value was seen when SASP was established. It is possible that SASP has a direct pharmacological effect on B cell GTase activ- ity and $G(0)$ value, and what makes this a potentially useful observation is that SASP is now an established second line antirheumatic agent for the treatment of RA $(49,50)$. Interestingly, serum concentrations of SASP in patients with RA are low, unrelated to clinical effects (51), and do not reach levels required to inhibit mitogen stimulation of lymphocytes (52), although in vitro inhibition of immunoglobulin synthesis and rheumatoid factor production is seen (53). Conceivably, SASP has an antibiotic effect on gut flora, thus altering the variety of antigens crossing the gut wall, or it may be that the intact SASP molecule exerts its effects by local suppression of lymphoid tissue in the small intestine (52), which in turn affects the lymphocyte traffic pathways of cells emerging from the gut-associated lymphoid tissue (54). In this respect, it may be more than coincident that RA intestinal mucin is abnormally glycosylated (55), and it remains to be seen whether there is an associated concomitant intestinal GTase defect. Preliminary in vitro investigations (data not shown) have been carried out to study the biochemical relationship between SASP, its metabolites sulphapyridine and 5-aminosalicylic acid (52), and GTase activity. In concentrations corresponding to those detected in the serum of SASP-treated patients $(0-10 \mu \mathrm{g} / \mathrm{ml})$, SASP has a direct dose-dependent inhibitory effect on human milk GTase and lymphocytic GTase from healthy and RA individuals, which is also observed indirectly when SASP is incubated with cultured lymphocytes. Similar effects are not observed when sulphapyridine and 5-aminosalicylic acid are used. These initial data would indicate that SASP and its metabolites do not have a direct synergistic effect on GTase activity. Perhaps SASP causes a GTase isoenzyme shift that proportionately increases IgG-galactosylation, or maybe SASP and/or its metabolites exhibit GTase synergism only in certain individuals who have RA.

Although IgG function may significantly alter as a result of oligosaccharide changes (24-27), evidence is lacking to link these changes with autoimmunity. The role played by oligosaccharides in causing IgG autosensitization and immune complex formation has been much debated (56), especially as the immunogenic site on IgG is thought to be localized to the $\mathrm{Fc}$ moiety $(57,58)$. There is, however, no evidence for amino acid changes in IgG-Fc, but immune complex formation in rheumatoid arthritis may occur either as a result of self-associating abnormally glycosylated immunoglobulins, or through the interaction with antibodies induced against $\mathrm{N}$-acetylglucosamine, the peptide, or peptide-oligosaccharide epitopes, that are normally unavailable for interaction. An analogous situation to this is found with recombinant human granulocyte macrophage colony stimulating factor, where antibodies are formed in patients against the recombinant protein only when the aglycosylated form is used (59). However, it has been observed that the in vitro binding of IgM rheumatoid factor to solid phase IgG-Fc fragments is influenced by the Fc-isotype rather than by the degree of Fc-glycosylation (60), but it has also been suggested that the Fc-oligosaccharides are unavailable for interaction, being hidden within the molecule, and it is the change in Ig conformation that results in functional abnormalities (23).

To investigate whether there is a humoral component associated with these glycosylation changes, the presence of antiGTase antibodies (abs) was sought in the serum of RA, non-autoimmune arthritis, and healthy individuals, and the presence of isotype-specific serum anti-GTase abs was detected. In RA, 
IgG anti-GTase antibody levels were significantly increased when compared to both the non-autoimmune arthritis (119\%) and healthy control populations (84\%), and $36 \%$ of the RA population had levels greater than healthy control mean +2 SD. In contrast, IgM anti-GTase levels were significantly decreased in both the RA $(-18 \%)$ and the non-autoimmune arthritis populations $(-53 \%)$ when compared to the healthy control population. No association was found between anti-GTase antibody levels and disease activity parameters or drug treatment. These data suggest that naturally occurring IgM anti-GTase antibodies are part of a normal immune regulatory mechanism associated with physiological glycosylation changes, whereas IgG anti-GTase antibodies result from isotype switching in RA that is associated with aberrant regulation of glycosylation. A further significant aspect of these data is that the presence of IgG anti-GTase antibodies is only associated with RA and not with non-autoimmune arthritis, whereas both these disease groups have less than normal levels of IgM. This raises the possibility that other immune-regulated glycosylation changes, as yet undetected, may be associated with other forms of rheumatic disease. It is also pertinent that these changes are unrelated to clinical disease activity, ESR, and IgM rheumatoid factor, which would suggest that they are not inflammation-related epiphenomena. These data now need to be further substantiated by investigating other diseases that are known to be associated with glycosylation changes (for example, systemic lupus erythematosus and Crohn's disease) or other rheumatic conditions (for example, osteoarthritis and reactive arthritis), by examining their temporal interrelationships and fully characterizing the binding and functional properties of anti-GTase antibodies.

This discussion has focused on IgG, and hence the B lymphocyte, but it is known that other immunologically pertinent molecules are glycosylated $(3,4)$ and previous data $(18)$ suggesting a reduction in $\mathrm{T}$ cell GTase activity has also been verified in this paper. $\mathrm{T}$ cell membrane proteins (i.e., $\mathrm{T}$ cell receptor, major histocompatability complex molecules, and lymphocyte functional antigens) and secreted lymphokines may be ábnormally glycosylated and also contribute to dysregulate the immune function.

In conclusion, correlation between B and T cell GTase activities has been observed in both normal and RA individuals, which would imply a mechanism of galactosylation control encompassing regulation of both lymphocytic populations. This regulatory mechanism may ensure certain levels of IgG glycosylation, and perhaps of other glycoproteins, in the normal population, which could become defective in RA. Serum anti-GTase abs may form part of this process, and there may be isotype switching of the naturally occurring IgM abs, found in healthy individuals, to RA-related IgG abs. Changes in these parameters may play a direct role in the pathogenesis of RA by forming part of the mosaic of susceptibility factors to RA, and manipulation of these changes, either by correcting the abnormal oligosaccharide or increasing the activity of GTase, may form the basis of a novel therapeutic approach to the treatment of RA. The fact that SASP has a marked and sustained effect on lymphocytic GTase and disease activity $(51,52)$ merits further investigation and the role played by the gut-associated lymphoid tissue in RA may provide a useful area in which to look. Perhaps glycosylation changes and carbohydrate transferase abnormalities are more widespread in autoimmune rheumatic disease, with each change resulting in a subtly different clinical variation.

\section{Acknowledgments}

Dr. Peter Lydyard, Professor Frank Hay, and Dr. Peter Delves are especially thanked for constructive advice in carrying out this research and for critical review of the manuscript. The authors would also like to thank Dr. Michael Snaith and Dr. Michael Shipley for allowing us to study their patients, Dr. Simon Thompson of The London School of Hygiene and Tropical Medicine for advice on statistical analysis, Dr. David Katz for providing tonsil tissue, Lorna Mackenzie for FACS ${ }^{\star}$ scanning of tonsil lymphocytes, Dr. Peter Nash and Dr. Roy Jefferis for generating the computer model depicted in Fig. 1, and Dr. Hilary Sinclair for helpful clinical discussion.

This work was made possible by grants from G. D. Searle and Co., Marks and Spencer Public Ltd. Co., The Middlesex Hospital Special Trustees Fast Track Scheme, and The Emily Le Rossignol Research Fund.

\section{References}

1. Horowitz, M. 1982. The glycoconjugates. Vols. III and IV. Academic Press, New York. 362 pp.

2. Bock, G., and S. Harnett. 1989. Carbohydrate recognition in cellular function. Ciba Foundation Symposium. John Wiley \& Sons Ltd., London. 249 pp.

3. Neel, D., B. Merlu, E. Turpin, C. Rabourdin-Combe, B. Mach, Y. Goussault, and D. J. Charron. 1987. Characterization of N-linked oligosaccharides of an HLA-DR molecule expressed in different cell lines. Biochem. J. 244:433-42.

4. Brenner, M. B., J. Mclean, H. Scheft, J. Riberdy, S. Ang, J. G. Serdman, P. Devlin, and M. S. Krangel. 1987. Two forms of the T cell receptor protein found on peripheral blood cytotoxic T lymphocytes. Nature (Lond.) 325:689-694.

5. Edberg, J. C., M. Barinsky, P. B. Radecha, J. E. Salmon, and R. P. Kimberley. 1990. Differences in glycosylation between FcrlII expressed on cultured monocytes and NK cells influence the ligand binding site. Arthritis Rheum. 33:S108. (Abstr.)

6. Yamaguchi, Y., and E. Ruoslahti. 1988. Expression of human proteoglycan in Chinese hamster ovary cells inhibits cell proliferation. Nature (Lond.). 336:244-246.

7. Roitt, I. M., R. A. Dwek, T. W. Rademacher, A. Alavi, J. S. Axford, K. B. Bodman, A. Bond, A. Cooke, F. C. Hay, D. A. Isenberg, et al. 1988. The role of antigen in autoimmune responses with special reference to changes in carbohydrate structure of $\mathrm{IgG}$ in rheumatoid arthritis. J. Autoimmun. 1:499-506.

8. Berger, E. G., M. Thurnher, and U. Muller. 1987. Galactosyltransferase and sialyltransferase are located in different subcellular compartments in HeLa cells. Exp. Cell. Res. 173:267-273.

9. Shur, B. D., and S. Roth. 1975. Cell surface glycosyltransferases. Biochim. Biophys. Acta. 415:473-512.

10. Schachter, H., and L. Rodén. The biosynthesis of animal glycoproteins. In Metabolic Conjugation and Metabolic Hydrolysis. W. H. Fishman, editor. Academic Press, New York. pp. 1-149.

11. McGuire, E. J., R. Kerlin, J. J. Cebra, and S. Roth. 1989. A human milk galactosyltransferase is specific for secreted, but not plasma IgA. J. Immunol. 143:2933-2938.

12. Shaper, N. L., J. H. Shaper, V. Bertness, H. Chang, I. R. Kirsch, and G. F. Hollis. 1986. the human galactosyltransferase gene is on chromosome 9 at band p13. Somatic Cell Mol. Genet. 12:633-636.

13. Russo, R. N., N. L. Shaper, and J. H. Shaper. 1990. Bovine $\beta 1,4$ galactosyltransferase: two sets of mRNA transcripts encode two forms of the protein with different amino-terminal domains. In vitro translation experiments demonstrate that both the short and the long forms of the enzyme are type II membrane-bound glycoproteins. J. Biol. Chem. 265:3324-3331.

14. Shur, B. D., and N. G. Hall. 1982. Sperm surface galactosyltransferase activities during in vitro compaction. J. Cell Biol. 95:567-573.

15. Bayna, E. M., R. B. Runyan, N. F. Scully, J. Reichner, L. C. Lopez, and B. D. Shur. 1986. Cell surface galactosyltransferase as a recognition molecule during development. Mol. Cell. Biochem. 72:141-151.

16. Bayna, M. E., J. H. Shaper, and B. D. Shur. 1988 . Temporally specific involvement of cell surface $\beta-1,4$ galactosyltransferase during mouse embryo morula compaction. Cell. 53:145-157.

17. Begovac, P. C., and B. D. Shur. 1990. Cell surface galactosyltransferase mediates the initiation of neutite outgrowth from PC12 cells on laminin. J. Biol. Chem. 110:461-470.

18. Axford, J. S., P. M. Lydyard, D. A. Isenberg, L. Mackenzie, F. C. Hay, and I. M. Roitt. 1987. Reduced B cell galactosyltransferase activity in rheumatoid arthritis. Lancet. ii:1486-1488. 
19. Delves, P. J., T. Lund, J. S. Axford, A. Alavi-Sadrieh, P. Lydyard, L. MacKenzie, M. D. Smith, and V. J. Kidd. 1990. Polymorphism and expression of the galactosyltransferase-associated protein kinase gene in normal individuals and galactosyltransferase-defective rheumatoid arthritis patients. Arthritis Rheum. 33:1655-1664.

20. Axford, J. S., P. Delves, A. Alavi, V. Kidd, T. Lund, P. Lydyard, D. A. Isenberg, and I. M. Roitt. 1988. Reduced lymphocytic galactosyltransferase activity in rheumatoid arthritis is not a result of enzyme inhibition nor gross structural changes in the gene. Br. J. Rheumatol. 27:45. (Abstr.)

21. Parekh, R. B., R. A. Dwek, B. J. Sutton, D. L. Fernandes, A. Leung, D. Stanworth, T. W. Rademacher, T. Mizuochi, K. Taniguchi, K. Matsuta, et al. 1985. Association of rheumatoid arthritis and primary osteoarthritis with changes in the glycosylation pattern of total serum IgG. Nature (Lond.). 316:452457.

22. Parekh, R. B., D. A. Isenberg, I. M. Roit, R. A. Dwek, and T. W. Rademacher. 1988. Age-related galactosylation of the $\mathrm{N}$-linked oligosaccharides of human serum IgG. J. Exp. Med. 167:1731-1736.

23. Lund, J., T. Tanaka, N. Takahashi, G. Sarmay, Y. Arata, and R. Jefferis. 1990. A protein structural change in aglycosylated human IgG3 correlates with a loss of binding and/or activation of Fc RI and Fc RIII receptors. Mol. Immunol. 27:1145-1154.

24. Leatherbarrow, R. J., T. W. Rademacher, R. A. Dwek, J. M. Woof, A. Clark, and D. R. Burton. 1985. Effector functions of a monoclonal aglycosylated mouse IgG2a: binding and activation of complement $\mathrm{CI}$ and interaction with human monocyte Fc receptor. Mol. Immunol. 22:407-415.

25. Nose, M., and H. Wigzell. 1983. Biological significance of carbohydrate chains of monoclonal antibodies. Proc. Natl. Acad. Sci. USA. 80:6632-6636.

26. Tsuchiya, N., T. Endo, K. Matsuta, S. Yoshinoya, T. Aikawa, E. Kosuge, F. Takeuchi, T. Miyamoto, and A. Kobata. 1989. Effects of galactose depletion from oligosaccharide chains on immunological activities of human IgG. J. Rheumatol. 16:285-290.

27. Heyman, B., M. Nose, and W. O. Weigle. 1985. Carbohydrate chains of monoclonal antibodies. J. Immunol. 134:4018-4023.

28. Parekh, R. B., D. A. Isenberg, B. M. Ansell, I. M. Roitt, R. A. Dwek, and T. W. Rademacher. 1988. Galactosylation of IgG-associated oligosaccharides is reduced in patients with adult and juvenile onset rheumatoid arthritis and is related to disease activity. Lancet. i:966-969.

29. Parekh, R. B., D. A. Isenberg, G. Rook, I. M. Roitt, R. Dwek, and T. Rademacher. 1989. A comparative analysis of disease-associated changes in the galactosylation of serum IgG. J. Autoimmun. 2:101-114.

30. Filley, E., A. Andreoli, J. Steele, M. Waters, D. Wagner, D. Nelson, K Tung, T. Rademacher, R. Dwek, and G. A. W. Rook. 1989. A transient rise in agalactosyl IgG correlating with free interleukin 2 receptors, during episodes of erythema nodosum leprosum. Clin. Exp. Immunol. 76:343-347.

31. Axford, J. S., N. Sumar, and K. B. Bodman. 1990. Longitudinal studies on abnormal IgG galactosylation in Lyme disease, tuberculosis, and Crohn's disease. Arthritis Rheum. 33:S85. (Abstr.)

32. Shoenfeld, Y., and D. A. Isenberg. 1989. The Mosaic of Autoimmunity. Elsevier Science Publishers, London. 521 pp.

33. Arnett, F. C., S. M. Edworthy, D. A. Block, D. J. McShane, J. F. Fries M. S. Cooper, L. A. Healy, S. R. Kaplan, M. H. Liang, H. S. Luthra, et al. 1987 The American Rheumatism Association 1987 revised criteria for the classification of rheumatoid arthritis. Arthritis Rheum. 31:315-324.

34. Isenberg, D. A., P. Martin, V. Hajirousou, A. Todd-Pokropek, A. H Goldstone, and M. L. Snaith. 1986. Haematological reassessment of rheumatoid arthritis using an automated method. Br. J. Rheumatol. 25:152-157.

35. Boyum, A. 1968. Isolation of mononuclear cells and granulocytes from human blood. Scand. J. Clin. Lab. Invest. 21:77-79.

36. Sumar, N., K. B. Bodman, T. W. Rademacher, R. A. Dwek, P. Williams R. B. Parekh, J. Edge, G. A. W. Rook, D. A. Isenberg, F. C. Hay, and I. M. Roitt 1990. Analysis of glycosylation changes using lectins. J. Immunol. Methods. 131:127-136.

37. Lunec, J., D. R. Blake, S. J. McCleary, S. Brailsford, and P. A. Bacon. 1985. Self-perpetuating mechanisms of Immunoglobulin $\mathbf{G}$ aggregation in rheumatoid inflammation. J. Clin. Invést. 76:2084-2090.

38. Kobata, A., T. Mizochi, T. Endo, and K. Furakawa. 1989. Function and pathology of the sugar chains of human immunoglobulin G. In Carbohydrate
Recognition in Cellular Function. Ciba Foundation Symposium. G. Bock and S. Harnett, editors. John Wiley \& Sons Ltd., London. 224-240.

39. Bodman, K. B., N. Sumar, L. MacKenzie, P. M. Lydyard, H. D. Sinclair, D. A. Isenberg, F. C. Hay, and I. M. Roitt. 1990. B cells from rheumatoid arthritis (RA) patients secrete agalactosylated immunoglobulin G. Clin. Exp. Rheumatol. 8(Suppl. 5):106.

40. Young, A., N. Sumar, K. Bodman, S. Goyal, H. Sinclair, I. M. Roitt, and D. A. Isenberg. 1991. Agalactosyl IgG: an aid to differential diagnosis in early synovitis. Arthritis Rheum. 34:1425-1429.

41. Pekelharing, J. M., E. Hepp, J. P. Kamerling, G. J. Gerwig, and B. Leijnse. 1988. Alterations in carbohydrate composition of serum IgG from patients with rheumatoid arthritis and from pregnant women. Ann. Rheum. Dis. 47:91-95.

42. Nicholas, N. S., and G. S. Panayi. 1988. Rheumatoid arthritis and pregnancy. Clin. Exp. Rheumatol. 6:179-182.

43. Isenberg, D. A., N. Sumar, K. Bodman, A. Young, I. M. Roitt, and J. L. Nelson. 1990. Fall in IgG(0) levels during pregnancy in patients with rheumatoid arthritis. Br. J. Rheumatol. 29:49. (Abstr.)

44. Quentin, E., A. Gladen, L. Roden, and H. Kresse. 1990. A genetic defect in the biosynthesis of dermatan sulfate proteoglycan: galactosyltransferase I deficiency in fibroblasts from a patient with a progeroid syndrome. Proc. Natl. Acad. Sci. USA. 87:1342-1346.

45. Singer, L., D. Crozier, and M. A. Moscarello. 1974. The levels of galactosyltransferase activity in sera from normal children and patients with cystic fibrosis. Clin. Biochem. 7:146-149.

46. Podolsky, D. K., M. M. Weiser, J. C. Westwood, and M. Gammon. 1977. Cancer associated serum galactosyltransferase activity. J. Biol. Chem. 252:18071813.

47. Bhattacharya, M., S. K. Chatterjee, and J. J. Barrow. 1976. Uridine 5 diphosphate-galactose glycoprotein galactosyltransferase activity in the ovarian cancer patient. Cancer Res. 36:2096-2101.

48. Podolsky, D. K., M. M. Weiser, K. J. Iselbacher, and A. M. Cohen. 1978 A cancer associated galactosyltransferase isoenzyme. N. Engl. J. Med. 299:703705.

49. Bax, D. E., and R. S. Amos. 1985. Sulphasalazine: a safe, effective agent for prolonged control of rheumatoid arthritis: a comparison with sodium aurothiomalate. Ann. Rheum. Dis. 44:194-198.

50. Pinals, R. S., S. B. Kaplan, J. G. Lawson, and B. Hepburn. 1986. Sulfasalazine in rheumatoid arthritis: a double-blind, placebo controlled trial. Arthritis Rheum. 29:1427-1434.

51. Pullar, T., J. A. Hunter, and H. A. Capell. 1985. Sulphasalazine in the treatment of rheumatoid arthritis: relationship of dose and serum levels to efficacy. Br. J. Rheumatol. 24:269-276.

52. Sheldon, P., C. Webb, and K. A. Grindulis. 1988. Effect of sulphasalazine and its metabolites on mitogen induced transformation of lymphocytes. Clues to its clinical action? Br. J. Rheumatol. 27:344-349.

53. Situnayake, R. D., and B. McConkey. 1985. Resin-coated 5-aminosalicylic acid (Asacol) in rheumatoid arthritis. Br. J. Rheumatol. 24:226-227.

54. Sheldon, P. J. 1987. HLA-B27 related arthritis, sulphasalazine and rheumatoid arthritis. Br. J. Rheumatol. 26:321-324.

55. Finnen, M. J., A. J. Collins, and L. J. Nofarianni. 1988. Defective glycocylation of gastric mucin in rheumatoid arthritis results in truncation of oligosaccharide chains. Br. J. Rheumatol. 27:26. (Abstr.)

56. Rademacher, T. W., R. B. Parekh, R. A. Dwek, D. A. Isenberg, J. S. Axford, and I. M. Roitt. 1988. The role of IgG glycoforms in the pathogenesis of rheumatoid arthritis. Springer Semin. Immunopathol. 10:231-249.

57. Male, D. K., and I. M. Roitt. 1981. Molecular analysis of complement-fixing rheumatoid synovial fluid immune complexes. Clin. Exp. Immunol. 46:521529.

58. Nardella, F. A., D. C. Teller, and M. Mannik. 1985. Studies on the antigenic determinants in the self-association of IgG rheumatoid factor. J. Exp. Med. 154:112-125.

59. Gribben, J. G., S. Devereux, N. S. B. Thomas, M. Keim, H. M. Jones, A. H. Goldstone, and D. C. Linch. 1990. Development of antibodies to unprotected glycosylation sites on recombinant human GM-CSF. Lancet. 335:434437.

60. Newkirk, M. M., A. Lemmo, and J. Rauch. 1990. Importance of the IgG isotype, not the state of glycosylation, in determining human rheumatoid factor binding. Arthritis Rheum. 33:800-809. 